\title{
Monitoring And Evaluation Of Teacher Effectiveness, A Case of Teacher Performance Appraisal And Development Tool In Public Secondary Schools In Nyandarua South Sub- County, Kenya
}

\author{
Khatete Ibrahim \\ University of Nairobi \\ Macharia Benson \\ University of Nairobi
}

\begin{abstract}
The purpose of this study was to investigate the monitoring and evaluation of teacher effectiveness a case of Teacher Performance Appraisal and Development tool (TPAD) in public secondary schools in Nyandarua South Sub-county, Nyandarua County, Kenya. The study was set to achieve three objectives; To determine the influence of teacher clog in and clog out exercise on teacher performance in public secondary schools in Nyandarua South Sub-county, Nyandarua county Kenya, to examine the influence of teachers' class registers on teacher performance in public secondary schools and to determine the influence of teachers adherence to school deadlines on their performance in public secondary schools. The study was guided by Performance Appraisal Model and benefited from descriptive survey research design. The target population was all 18 public secondary schools in Nyandarua south sub-county. The respondents were 18 Principals, 18 deputy Principals 20 H.O.D s and 90 teachers being a sample size of 30 percent of the entire public school population. Teachers were sampled using simple random sampling to obtain five teachers in every sampled school, totaling to 90 teachers. Questionnaires, interview guide and document analysis guide formed the instruments used for data collection. Descriptive statistics was used to analyze collected data. The study findings revealed that monitoring of teachers on their reporting on duty and leaving from duty improved the teachers stayed in school hence more contact time between teachers and learners in school, the monitoring of teacher class attendance improved teachers' syllabus coverage. A majority of the schools are completing the syllabus coverage in time. The teachers are now able to do revision as they prepare students for examinations and promotion to the next grades. The meeting of deadlines has created a positive culture among the teachers in the schools. The teachers now look at meeting the deadlines set by the schools as a good thing that is making them more responsible. Lastly the strategies being used to monitor teachers attendance on their duties has resulted into impressive performance of teacher in their duties. Based on the findings and Conclusions of the study, it is recommended that TPAD tool for monitoring teachers on time management should be emphasized. The practice should be borrowed and applied to other areas of school operations.
\end{abstract}

\section{Background to the Study}

\section{INTRODUCTION}

Teachers are the primary implementers of the curriculum and single major factor that affect learners' achievement in school (Almeida, 2017). It is important for schools to put in place and enhance systems to increase teachers' supervision, monitoring and evaluation. Several tools are being used including teacher performance appraisal and development system. Performance appraisal involves an employee sitting down with his or her immediate supervisors to set targets establish strategies to meet the targets, evaluate the degree at which 
the employee is meeting the employer demands for the realization of the targets and identify gaps. The objective is to improve the overall productivity of the employee to the organization. It is prudent to put in place a measure to rate the employees' performance as the backbone of any organization's management strategy. Organizations usually measure employees' performance by assessing how much contribution the employee is making towards its growth or how effective the employee is in meeting the targets and objectives of the organization (Elliot, 2015).

Employee performance depends upon several factors; a conducive work environment, work profile, compensation, bonus system, job satisfaction, organization policies and embracing of technology. The same factors play important role in determining the employee productivity and hence the overall organizational development (Morphy 2013).

In the United Kingdom (UK), teacher evaluation and appraisal systems are used to monitor teacher performance for provision of quality education in learning institutions. The employer has implemented two appraisal models for teacher appraisal which include appraisal of professional development model and the accountability model. These models have helped to increase teacher performance in all learning institutions where the employer keeps close watch on the day to day instructional process (Morphy, 2013).

In Botswana, teacher appraisal tools have helped improve the relationship between working and career development. The development of the interconnected model to evaluate teacher appraisal process has increased the capacity of teacher performance (Elliot, 2015). In Uganda, performance appraisal is used to influence teacher performance in public and private educational institutions. The teacher appraisal tool is used to align teaching staff to the education strategic goals whose central pillar is performance management (Kyakulumbye, 2013). However, the different tools implemented in various countries for teacher performance appraisal are reported to lack effective contribution to teacher performance in classrooms which has a close relationship with management of time.

Monitoring and evaluation of time include checking the construction and implementation of time tables, distribution of subjects on the timetable and total number of periods taken by teachers. The other aspect of monitoring and evaluation will be on lesson planning, regularity and punctuality of teachers in school and advance planning of class activities. Monitoring of time allocation to teaching and learning processes to teachers individually and in the school in general including preparation of co-curricular activities for students is very essential.

Timely syllabus coverage is critical to learners as pertains to performance in end of the year and end of the secondary school course examination; Kenya Certificate of Secondary Examination (KCSE). Both examinations are used for students' promotion to the next grades and for selection and choice of courses at higher education institutions (Amadalo, Shikuku \& Wasike, 2012). However, efforts to improve teacher effectiveness in education is pulled back by woos such as inadequate coverage of syllabus out of mismanagement and wastage of quality teaching time by teachers as they drag their feet into class. It is also portrayed as some teachers spend very little of the stipulated time with learners in class during the lesson interactions between teachers and learners.

Mutia (2016) found that when teachers relate well, and utilize maximum the time allocated to them, there will be timely syllabus coverage and a boost on the prospects of good performance at end of the year and end of the circle examination. Therefore if time was properly managed 
then various tasks by the teachers would be completed in good time demonstrating teacher effectiveness in the realization of school goals and objectives.

In Kenya, the Government introduced performance management in 2003 as part of the public sector reform programme. This was to ensure that all public officers except for teachers were put under performance management programmes. In January 2016, Teachers Service Commission (TSC) rolled out Performance Contracting (PC) for heads of institutions and Teacher Performance Appraisal and Development tool (TPAD) for all teachers. The PC and TPAD are the performance monitoring and evaluation tools meant to generate up-to-date data for planning and enhancing of the quality of teaching and ultimately improve learning outcomes in the institutions.

Appraisal of time management is a crucial element on the TPAD tool. Kayode and Kayode (2015) observed that time is a resource that stipulates the effective management of learning and utilization of learning resources. It is imperative therefore that it should be well monitored. Muhammad, Khan, Farooqi, Khalil, and Faisal (2016) state that monitoring and evaluation of time helps teachers to ensure that they plan their school activities and lesson attendance to minimize wastage through absenteeism and idling in class. Whereas other scholars have looked at importance of time management in general, they have not examined how the items in the TPAD tool affect the teacher performance in their duties especially on the learners' academic performance hence this study.

\section{Statement of the Problem}

The introduction of TPAD by the TSC in January 2016 for teachers' aimed at monitoring the curriculum implementation and the accountability in the utilization of resources. The TSC lauded this initiative as a milestone in its effort to curb teacher absenteeism and improving teaching/learning interactions and outcomes. However, this effort has faced a lot of opposition from teachers and their trade union, especially Kenya National Union of Teachers (KNUT). The high expectations required on the performance appraisal tool is making teachers to fill them mechanically to please the employer rather than providing information reflecting on the actual performance. It was in this regard that this research was intended to find out how monitoring and evaluation of teacher effectiveness by use of Teacher Performance Appraisal and Development tool (TPAD) in Nyandarua South Sub-county, Nyandarua County, Kenya is affecting learners performance.

\section{Purpose of the Study}

The purpose of this study was to investigate the effect of monitoring and evaluation of teacher effectiveness in secondary schools using a case of time management in the Teacher Performance Appraisal and Development tool (TPAD) in Nyandarua South Sub-county, Nyandarua County, Kenya.

\section{Objectives of the Study}

The study was guided by the following objectives;

i. To determine the influence of teacher clog in and clog out exercise on effectiveness of teacher performance in public secondary schools in Nyandarua South Sub-county, Nyandarua county Kenya

ii. to examine the influence of teachers' signing of class attendance registers on effectiveness of teacher performance in public secondary schools

iii. to determine the influence of adherence to school deadlines on effectiveness of teachers performance in public secondary schools 


\section{Research Questions}

The study sought to answer the following research questions;

i. How does the teacher clog in and clog out exercise influence the effectiveness of teachers' performance in public secondary schools in Nyandarua South Sub-County, Nyandarua County, Kenya?

ii. To what extent does the use of teachers' class attendance register influence effectiveness of teacher performance in public secondary schools?

iii. How does adherence to school deadlines influence effectiveness of teachers' performance in public secondary schools?

\section{Significance of the Study}

The study findings may provide feedback on effectiveness of Teacher Performance Appraisal and Development tool to the teachers' service commission (TSC) management who can use them in their effort to improve teacher time management. The research results may also be beneficial to the Kenya National Union of Teachers (KNUT) and Kenya Post Primary Education and Tertiary institutions (KUPPET) to appreciate teachers' time management to benefit the learner. To the teachers themselves the study findings may be an eye opener for them to plan to manage available time to benefit the learners and themselves at large.

\section{Delimitation of the Study}

The study focused on public secondary schools in Nyandarua South Sub-County, Nyandarua County, Kenya. The study was also delimitated to secondary schools teachers employed by TSC, principals and deputy principals leaving out other stakeholders taking part in teacher performance appraisal like the QASOs. The study also focused only on three issues on the time management as interpreted from the Teachers Service Commission's Teacher Performance Appraisal and Development tool.

\section{Assumptions of the Study}

The study was based on the assumption;

i. That teachers' performance appraisal had been implemented in all public secondary schools,

ii. That teachers' performance appraisal tool is aimed at improving time management in schools

\section{DEFINITION OF SIGNIFICANT TERMS AND ACRONYMS}

Appraisal of time management; refers to the secondary school teachers' ability to manage teaching time through consistent class attendance, adherence to the school timetable, attendance of other school activities and staff meetings.

Feedback; refers to the comments and commendations by appraiser regarding the teacher overall performance towards achieving the required set targets.

Performance Appraisal; refers to a method used by principals and deputy principals for monitoring and evaluating a secondary school teacher's performance at the secondary school and involves, setting of targets, periodic assessment, feedback on evaluation, performance based consultations, gathering evidence to demonstrate performance rating, identification of the performance gaps and planning on the employee development and support measures.

Performance Management; refers to a systematic process of improving secondary schools' performance by developing individual teachers' performance targets. 
Teacher Performance; refers to teacher's demonstrated impact on secondary school students learning established through student achievement test scores, observed pedagogical practices, molding of an all rounded learner who is socially, morally, spiritually, emotionally and productive to the society.

\section{THEORETICAL FRAMEWORK}

This study was anchored on goal setting theory. The theory was put forward by Edwin .A. Locke in 1960. The theory stipulates that goal setting is essentially linked to task performance. The theory's principles state that specific and challenging goals along with appropriate feedback contribute to higher and better task performance. This model recommended the annual appraisal system where every staff member is expected to fill up yearly work to report on the progress of the task assigned as agreed earlier in the year. At the end of the yearly work plan is used to evaluate the performance of the staff for the whole year. At the end of the yearly work plan is used to evaluate the performance of the staff for the whole year.

According to Locke (1960), people work hard to achieve goals to satisfy their emotions and desires. Locke further emphasizes that for goal setting theory to work employees must show commitment to the goal which they set. He defines commitment as one's attachment to or determination to reach a goal, regardless of the goals origin. Better and appropriate feedback of results directs the employee behaviour and contributes to higher performance than absence of feedback.

The theory was therefore appropriate to this study since the Teacher performance Appraisal and Development tool has been used by the teachers' employer, Teacher Service Commission (TSC) to set targets for teacher performance.

\section{RESEARCH METHODOLOGY}

This study employed descriptive survey research design. Descriptive research design is scientific method which involves observing and describing the behavior of a subject without influencing it in any way (Kothari 2003). The design was chosen because it was deemed appropriate in collection of both quantitative and qualitative data. Using the design, the researcher attempted to get answers to questions by analyzing the variables in teacher performance appraisal tool on the influence on teacher performance in secondary schools in Nyandarua South Sub-County, Nyandarua County, Kenya.

\section{Target Population}

According to Matula et al, (2018) target population refers to the entire group of individuals or objects that the researcher has chosen to study. This study was carried out in Nyandarua South Sub-County, Nyandarua County, Kenya. It targets 36 principals, 36 deputy principals, 270 teachers, 20 TSC appointed HODs and 1 T.S.C Sub-County Director of Education.

\section{Sample Size and Sampling Procedure}

To get samples, the researchers obtained a list of schools from the Sub-County Director of Education and the number of TSC personnel at the Sub-County. According to Mugenda and Mugenda (2003) a sample size of $10-30 \%$ or more of the respondents can represent the target population.

To select individual schools to participate in the study, simple random sampling was used to sample 50 percent of the secondary schools in the sub-county to ensure a representative sample for the entire group due to the small size of the target population, totaling to 18 schools. Census sampling was used to sample the 18 principals their deputies in the selected 
secondary schools. Simple random sampling was used to select 30 percent of the teachers to participate in the study adding up to 90 teachers. Purposive sampling was used to sample 50 percent of the TSC appointed HODs in the selected secondary schools, as well as the TSC SubCounty Director of Education because of their role in teacher performance appraisal.

Table 3.1 Sampling Matrix

\begin{tabular}{lccc}
\hline $\begin{array}{l}\text { CATENGORY OF } \\
\text { POPULATION }\end{array}$ & $\begin{array}{c}\text { TOTAL } \\
\text { POPULATION }\end{array}$ & $\begin{array}{c}\text { SAMPLING } \\
\text { PROCEDURE }\end{array}$ & $\begin{array}{c}\text { SAMPLE } \\
\text { SIZE }\end{array}$ \\
\hline TSC Sub -County & 1 & Purposive & 1 \\
Director & 36 & Census & 18 \\
Principals & 20 & Purposive & 18 \\
HODs & 36 & Purposive & 18 \\
Deputy Principals & 270 & Simple Random & 90 \\
Teachers & $\mathbf{3 4 3}$ & & $\mathbf{1 1 9}$ \\
\hline TOTAL & & & \\
\hline
\end{tabular}

\section{Research Instruments}

The study used questionnaires and an interview guide schedule to gather primary data. There were four sets of questionnaires: principals' questionnaire, teachers' questionnaire, HODs questionnaire and Deputy Principals' questionnaire. Each questionnaire comprised of two sections A and B. Section A focused on demographic information, section B focused on various aspects of teachers time management. The interview guide was used to conduct a face-to-face interview with the Sub-County Director of Education the implementation of TPAD in the subcounty.

\section{Data Analysis Techniques}

For this study collected data was checked for completeness, edited and coded for analysis. It was computed using statistical package for social sciences (SPSS) version 24. Quantitative data was analyzed using descriptive statistics to yield the frequencies and percentages. Qualitative data was organized into themes and patterns based on the study variables and analyzed in line with the objectives of the study.

\section{DATA ANALYSIS, PRESENTATION, INTERPRETATION AND DISCUSSIONS Questionnaires Response Rate}

After data collection the research tools were checked for completeness to determine their suitability in answering the study questions. Therefore the response rate was determined. Table 1 shows the return rate of the responses from the expected respondents of this study.

Table 1: Questionnaires Response Rate

\begin{tabular}{lccc}
\hline Target Category & Number Targeted & Number Responded & Response Rate \\
\hline Teachers & 90 & 83 & $92.2 \%$ \\
HODs & 20 & 12 & $60.0 \%$ \\
Deputy Principals & 18 & 18 & $100.0 \%$ \\
Principals & 18 & 18 & $100.0 \%$ \\
\hline
\end{tabular}

From table 1 the average instruments' return rate was 88 percent.

The response rate was considered adequate as according to Idrus and Newman (2002) a response rate of 50 percent is good enough for the social studies. 
Ibrahim, K., \& Benson, M. (2020). Monitoring And Evaluation Of Teacher Effectiveness , A Case Of Teacher Performance Appraisal And Development Tool In Public Secondary Schools In Nyandarua South Sub- County, Kenya. Germany. Advances in Social Sciences Research Journal, 7(1) 320-329.

\section{Appraisal of Time Management and Teacher performance}

Objective one of the study sought to determine the influence of teacher clog in and clog out exercise on teacher performance in public secondary schools in Nyandarua South Sub-county, Nyandarua county Kenya.

In order to generate data on this objective, the researchers sought opinions of the respondents on various issues around the teacher clog in and clog out register. The respondents were asked whether teachers clog in and clog out when they report on duty in the morning and evening when the go home respectively. All the respondents; principals, deputy principals, heads of departments and teachers indicated that there is a special register in the school where teachers clog in and clog out every day. During the interview with the principals it was revealed that initially teachers were un-comfortable and resisted to fill in the register. Some would sign in according to the time indicated by the last person before them in the register even when they have come late. These cases however have reduced drastically.

On the issue of how the clogging in and clogging out has impacted on the teacher performance the data collected is presented in table 2

Table 2 impact of the clogging in and clogging out on teacher performance

\begin{tabular}{lccccccccc}
\hline Statement & \multicolumn{2}{c}{ Principal } & \multicolumn{2}{c}{ Deputy } & \multicolumn{2}{c}{ HODs } & \multicolumn{2}{c}{ Teachers } \\
& Freq & $\%$ & freq & $\%$ & Freq & $\%$ & freq & $\%$ \\
\hline Teachers report before 8.00 am & 14 & 78 & 15 & 83 & 10 & 83 & 60 & 60.3 \\
& & & & & & & & \\
Teachers report after 8.00 am & 4 & 22 & 3 & 17 & 2 & 17 & 23 & 27.7 \\
Teachers stay in school till 5.00 pm & 12 & 67 & 10 & 56 & 8 & 67 & 67 & 80.7 \\
& & & & & & & & \\
\hline Teachers leave earlier than 5.00 pm & 6 & 33 & 8 & 44 & 4 & 33 & 16 & 19.3 \\
\hline
\end{tabular}

From the data in table 2 it can be observed that generally there is an improvement on the teachers reporting time and time for leaving for home every day. A majority of the teachers were reported to be reporting to school before 8.00 o'clock and staying in school till 5.00 o'clock. The average response rates from the four types of respondents were 76.1 percent and 67.7 percent on reporting time and time for leaving for home respectively. It was observed during the interview with the principals of the schools that teachers are complying readily on the stipulated time for reporting to school and leaving for home after the day's activities.

It was imperative to know what teachers do on reporting to school on time every day. The responses on this issue are reported in table 3.

Table 3: teachers' engagement when they report to school on time

\begin{tabular}{|l|c|c|c|c|c|c|c|c|}
\hline Statement & \multicolumn{2}{|c|}{ principals } & \multicolumn{2}{c|}{ d/principals } & \multicolumn{2}{c|}{ HODs } & \multicolumn{2}{c|}{ teachers } \\
\hline & Freq. & $\%$ & Freq. & $\%$ & Freq. & $\%$ & Freq. & $\%$ \\
\hline Prepare for days lessons & 15 & 83.3 & 14 & 77.8 & 10 & 83.3 & 65 & 78.3 \\
\hline Give remedial work & 12 & 66.7 & 10 & 55.6 & 8 & 66.7 & 60 & 72.3 \\
\hline Mark assignments & 13 & 72.2 & 12 & 66.7 & 11 & 91.7 & 71 & 85.5 \\
\hline Meet students for guidance & 5 & 27.8 & 3 & 16.7 & 2 & 16.7 & 18 & 21.7 \\
\hline Supervise preps & 5 & 27.8 & 4 & 22.2 & 5 & 41.7 & 20 & 24.1 \\
\hline Engage in idle talks & 1 & 5.6 & 0 & 0 & 2 & 16.7 & 5 & 6.0 \\
\hline
\end{tabular}


From data in table 3 it is seen that teachers engage themselves in various activities as they report early to school. Unlike previous time before the introduction of TPAD, teachers' engagement in idle talks is minimal as attested by the lowest response from the respondents across all categories.

The second objective of the study examined the influence of teachers' class registers on teacher performance in public secondary schools. Schools have put in place various strategies to monitor teacher activities in class. The most common strategy is the use of teacher register where the class prefect with or without the knowledge of the teachers record the time the teacher enters the class to teach and leave after teaching. It therefore important to know how the register is filled and the information it contained.

The principals of schools were asked whether they maintain the strategy in their schools. The responses indicated that 67 percent of the principals have introduced the strategy in their schools. The remaining 37 percent said that they do not use the strategy but rely on the teachers' self confession in the records of work that they attend to all their lessons. To collaborate the finding the deputy head teachers and teachers were asked to respond to the item. The responses are as tabulated in table 4.

Table 4: Presence of teachers lesson attendance register in class

\begin{tabular}{lcccccc}
\hline Responses & D/Principal & & HODs & \multicolumn{3}{c}{ Teachers } \\
\hline Yes & Freq. & $\%$ & Freq. & $\%$ & Freq. & $\%$ \\
No & 14 & 77.8 & 10 & 83.3 & 70 & 84.3 \\
\hline
\end{tabular}

Table 4 indicates that the use of teacher lesson attendance register in class is a popular strategy in the schools. The teachers voted it at 84.3 percent. The comments from the principals during the interview revealed that the teachers are now utilizing time allocated to them at maximum. The principals said that teachers report to their lessons in time and stay until end of their stipulated time for the lesson. 'The initiative has assisted many schools to complete the syllabus in good time for revision' as quoted from one of the principals.

The third objective of the study was to establish the influence of teachers' adherence to school deadlines on their performance in public secondary schools. in school there are many deadlines put in place to help teachers work and produce timely results. Among the deadlines are; for submission of set examinations and submission of marks.

The table on these initiatives in schools is as reported in table 5.

Table 5: Responses on meeting deadlines by the teachers

\begin{tabular}{lcccccccc}
\hline Statement & \multicolumn{2}{c}{ Principal } & \multicolumn{2}{c}{ D/Principal } & \multicolumn{2}{c}{ HODs } & \multicolumn{2}{c}{ Teachers } \\
\hline Meeting deadlines & Freq. & $\%$ & Freq. & $\%$ & Freq. & $\%$ & Freq. & $\%$ \\
Always & 14 & 77.8 & 15 & 83.3 & 10 & 83.3 & 75 & 90.4 \\
Sometimes & 3 & 16.7 & 2 & 11.1 & 2 & 16.7 & 8 & 9.6 \\
Rarely & 1 & 5.6 & 1 & 5.6 & 0 & & 0 & \\
\hline
\end{tabular}

From table 5 it can be concluded that there is positive response among the teachers on meeting set deadlines in the school. Ninety percent of the teachers affirmed that they always met set deadlines. This is an indicator of positive performance by the teachers in the school.

It was important to know how the teachers' positive thinking on the use of the monitoring tool is benefitting the learners. During the interview with the principals of the schools it emerged 
that schools are now registering improvements in academic performance among learners as retorted by one principal;

"Teachers are so positive about their work that for the last two years we have registered improved performance. We have moved nearly two points in mean score. In 2016 we had a mean score of 4.57 but in the $2018 \mathrm{KCSE}$ results we realized a score of 6.43 a positive change of 1.86. There is also marked enthusiasm among the teachers. Teachers report in good time for duty every morning and stay till 5.00 pm"

The responses from all the principals on how they felt about the monitoring of the teachers' time management on a likert scale yielded the results as tabulated in table 4.7. the principals were to express their level of level of agreement to the provided statements. The key used included SA - Strongly Agree, A = Agree, D = Disagree and SD = Strongly Disagree. The data collected were presented on Table 6.

Table 6: Principals' Responses on various Appraisals on Time Management and Teacher Performance

\begin{tabular}{|c|c|c|c|c|c|c|c|c|c|}
\hline \multirow{2}{*}{\multicolumn{2}{|c|}{$\begin{array}{l}\text { Appraisal of time } \\
\text { management }\end{array}$}} & \multicolumn{2}{|c|}{ SA } & \multicolumn{2}{|c|}{ A } & \multicolumn{2}{|c|}{ D } & \multicolumn{2}{|c|}{ SD } \\
\hline & & $\mathbf{F}$ & $\%$ & f & $\%$ & $\mathbf{F}$ & $\%$ & $\mathbf{F}$ & $\%$ \\
\hline a) & $\begin{array}{l}\text { Appraising teachers on } \\
\text { attending class on time } \\
\text { improves their } \\
\text { performance }\end{array}$ & 16 & 88.9 & 2 & 11.1 & 0 & 0.0 & 0 & 0.0 \\
\hline b) & $\begin{array}{l}\text { Appraising teachers on } \\
\text { timely preparation of } \\
\text { professional records } \\
\text { improve their } \\
\text { performance }\end{array}$ & 9 & 50.0 & 3 & 16.7 & 4 & 22.2 & 2 & 11.1 \\
\hline
\end{tabular}

According to information presented in Table 6, 88.9 percent of the principals strongly agreed that appraisal of time management has improved teachers school attendance. This in turn has improved both the teachers and the learners' performance. The results however disagree with arguments by Green and Skinner (2005) who opined that appraisal of time management points a high inconsistency between individual's estimations of time usage and output result. The findings are consistent with Mohanty (2003) argument who stated that appraisal of time management is an indispensable element of school organization. It is the art of arranging, scheduling and budgeting one's time to achieve objectives.

\section{CONCLUSIONS, RECOMMENDATIONS}

The study findings have revealed that;

a. The data collected for the study revealed that monitoring of teachers on their reporting on duty and leaving from duty improved the teachers stayed in school hence more contact time between teachers and learners in school.

b. The monitoring of teacher class attendance improved teachers' syllabus coverage. A majority of the schools are experiencing early syllabus coverage. The teachers are now able to do revision as they prepare students for examinations and promotion to the next grades.

c. Meeting of deadlines has created a positive culture among the teachers. The teachers are now looking at meeting the deadlines set by the schools as a good thing making them more responsible. 
d. the strategies being used to monitor teachers attendance on their duties has resulted into impressive teacher performance of their duties

\section{RECOMMENDATIONS OF THE STUDY}

Based on the findings and Conclusions of the study it recommended that TPAD tool for monitoring teachers on time management should be emphasized. The practice should be borrowed and applied to other area of school operations.

\section{References}

Almeida, J.C. (2017) Universidad Fernando Pessoa, Porto. Portugal Teacher performance evaluation; the importance of performance standards. Int J Pharm, 149: 255-265.

Aloo J.O, Ajowi,J.O and Aloka P.J.O (2017) influence of Teacher performance. Appraisal on effectiveness in curriculum Evaluation in Kenya public secondary schools. Academic journal interdisciplinary studies.

Edabu, P. Sinan, G. H., \& Wagithunu, M.N. (2018). Influence of time resource management on academic performance of trainees in public primary Training colleges in Kenya. EPH - International Journal of Educational Research. Vol 2 No 1.

Elliot, K. (2015). Teacher Performance Appraisal More about Performance or Development? Australian Journal of Teacher Education, 40(9), pp.12 - 19.

Kayode, G.M and Ayodele, J.B (2015) Impact of teacher appraisal of time management on secondary school students' academic performance in Ekiti state Nigeria.

Kyakulumbye, S. (2013). Appraisal System And Staff Performance In Selected Secondary Schools In Uganda: A Comparative Case Against Public Service Appraisal System, The 2013 The West East Institute 29WEI International Academic Conference Proceedings, Orlando, USA Available at https://www.westeastinstitute.com/wpcontent/uploads/2013/04/ORL13-206-Stephen-Kyakulumbye.pdf

Mbalaka, P.M. (2016) Teachers relational factors influencing timely syllabus coverage in public secondary school within Migwani Sub-County Kitui County, Kenya.

Morphy, R. (2013). Testing Teachers. London: The Sutton Trust.

Mugenda, O.M. and Mugenda, A.G. (2003) Research methods quantitative and qualitative approaches Nairobi Kenya Acts press.

Muhammad, H., Khan, A., Farooqi, M.T.K., Khalil, A. \& Faisal, I. (2016) Exploring relationship of appraisal of time management with teacher's performance. Bulletin of Education and Research, Vol. 38, No. 2 pp. 249-263

PC \& TPAD, (2018). Teachers Service Commission, available at https://www.tsc.go.ke/index.php/mediacentre/downloads

Sahito, Z., Khawaja, M., Panhwar, U.M., Siddiqui, A. \& Saeed, H. (2016). teachers' appraisal of time management and the performance of students; a comparison of government and private schools Hyderabad, Sindh, Pakistan 